See Article page 2451.

\section{Commentary: Alas, we are not yet zebrafish}

\author{
Christopher T. Ryan, MD, and Todd K. Rosengart, MD
}

The relative inability of the adult heart to replenish its cardiomyocytes and the tendency of the myocardium to generate reactive fibrosis to injury represent significant barriers to native myocardial regeneration and the preservation of its function. ${ }^{1-5}$ The field of cardiac regenerative medicine has developed to address this challenge, with the ultimate goal of restoring the cardiomyocyte population with wellintegrated and contractile cells.

Cardiac regenerative strategies can be broadly divided into cellular and noncellular approaches. Cellular approaches to myocardial regeneration involve implantation of exogenous or autogenous cells into the injured myocardium, most prominently using stem cells or other precursor cells such as myoblasts. Little evidence has been found, however, to suggest that these implanted stem cells can differentiate into cardiomyocytes, and cellular strategies have been further hampered by the poor engraftment and survival of implanted cells. ${ }^{6-8}$

Noncellular myocardial regenerative strategies have typically involved local or systemic administration of genes, small molecules, and/or growth factors to increase cardiomyocyte number by directly reprogramming cardiac fibroblasts in regions of myocardial scar into induced cardiomyocytes, recruiting native cardiac progenitor cells, enhancing the survival of threatened host cardiomyocytes in ischemic zones, or inducing the proliferation of native cardiomyocytes. $^{7}$ These strategies bypass the limitations of cell implantation noted previously but require a thorough mechanistic understanding of the underlying biology of myocardial injury and recovery.

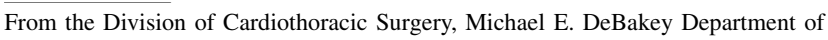
Surgery, Baylor College of Medicine, Houston, Tex.

Supported by the National Heart Lung and Blood Institute through the Research Training Program in Cardiovascular Surgery (T32HL139430; to C.T.R).

Disclosures: Authors have nothing to disclose with regard to commercial support.

Received for publication Dec 9, 2019; revisions received Dec 9, 2019; accepted for publication Dec 10, 2019; available ahead of print Jan 31, 2020.

Address for reprints: Todd K. Rosengart, MD, Michael E. DeBakey Department of Surgery, 6501 Fannin St, Suite NC114, One Baylor Plaza, MC 390, Houston, TX 77030 (E-mail: Todd.Rosengart@bcm.edu).

J Thorac Cardiovasc Surg 2020;159:2457-8

$0022-5223 / \$ 36.00$

Copyright (C) 2020 by The American Association for Thoracic Surgery

https://doi.org/10.1016/j.jtcvs.2019.12.045
}

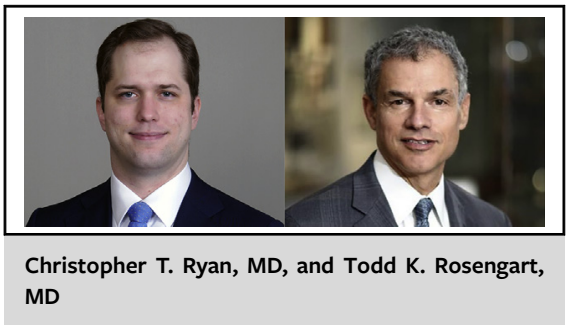

\author{
CENTRAL MESSAGE \\ Leveraging intrinsic cardiomyo- \\ cyte repair mechanisms may \\ allow for restoration of myocar- \\ dial function in heart failure, but \\ extensive further preclinical vali- \\ dation of these strategies is \\ needed.
}

Multiple groups have dramatically expanded the knowledge base in cellular and noncellular regenerative strategies in recent years but translating this body of work from rodent models to human cells remains a persistent challenge. For example, in this issue of the Journal, Sadek and Porrello interestingly note that extensive investigations in animal models have shown that blockade of thyroid signaling can induce replication of native adult cardiomyocytes after injury in mice, but there is no evidence this biologic mechanism is relevant to humans. ${ }^{8-10}$ Patients with hypothyroidism, for example, are not known to exhibit myocardial proliferative activity nor demonstrate recovery from heart failure. In fact, the presence of hypothyroidism in patients with heart failure is associated with increased morbidity and mortality with impaired systolic and diastolic function. ${ }^{10,11}$ Assuming the validity of the paradigm originally presented by Hirose and colleagues $^{12}$ that is the subject of Sadek and Porrello's commentary, this discordance reflects the perennial challenge of translating observations in lower-order species to the human substrate. Recent challenges to human cell reprogramming due to epigenetic repressions of the human genome reflect a similar such obstacle. ${ }^{13}$ The pleiotropic effects of thyroid hormone at different levels of expression may represent alternative observations for these disparate effects. ${ }^{14}$ 
As new findings in cardiac regenerative biology progress toward likely inevitable application to our patients, the role of the cardiac surgeon in these therapies remains to be defined. Treatments that are adjunctive to concomitant open surgical procedures seem obvious. Other opportunities will present themselves for surgeons to also engage in catheter-based endocardial or thoracoscopic epicardial approaches to direct intramyocardial delivery of regenerative agents, which possesses essential pharmacokinetic advantages over intracoronary or systemic delivery approaches. ${ }^{15}$ As the prevalence of heart failure continues to rise, cardiac surgeons must continue to be intimately involved in the preclinical validation and clinical testing of these promising new therapeutic approaches to realize their full potential for our patients.

\section{References}

1. Bergmann O, Bhardwaj RD, Bernard S, Zdunek S, Barnabé-Heider F, Walsh S, et al. Evidence for cardiomyocyte renewal in humans. Science. 2009;324:98-102.

2. Laflamme MA, Murry CE. Heart regeneration. Nature. 2011;473:326-35.

3. Prabhu SD, Frangogiannis NG. The biological basis for cardiac repair after myocardial infarction. Circ Res. 2016;119:91-112.

4. Beach JM, Mihaljevic T, Rajeswaran J, Marwick T, Edwards ST, Nowicki ER, et al. Ventricular hypertrophy and left atrial dilatation persist and are associated with reduced survival after valve replacement for aortic stenosis. J Thorac Cardiovasc Surg. 2014;147:362-9.e8.

5. González A, Schelbert EB, Díez J, Butler J. Myocardial interstitial fibrosis in heart failure. J Am Coll Cardiol. 2018;71:1696-706.

6. Balsam LB, Wagers AJ, Christensen JL, Kofidis T, Weissman IL, Robbins RC. Haematopoietic stem cells adopt mature haematopoietic fates in ischaemic myocardium. Nature. 2004;428:668-73.

7. Rosengart TK, Fallon E, Crystal RG. Cardiac biointerventions: whatever happened to stem cell and gene therapy? Innovations (Phila). 2012;7:173-9.

8. Abdelwahid E, Kalvelyte A, Stulpinas A, de Carvalho KAT, Guarita-Souza LC, Foldes G. Stem cell death and survival in heart regeneration and repair. Apoptosis. 2016;21:252-68.

9. Sadek HA, Porrello ER. Neonatal heart regeneration: moving from phenomenology to regenerative medicine. J Thorac Cardiovasc Surg. 2020;159:2451-5.

10. Kannan L, Shaw PA, Morley MP, Brandimarto J, Fang JC, Sweitzer NK, et al. Thyroid dysfunction in heart failure and cardiovascular outcomes. Circ Heart Fail. 2018;11:e005266.

11. Klein I, Danzi S. Thyroid disease and the heart. Circulation. 2007;116:1725-35.

12. Hirose K, Payumo AY, Cutie S, Hoang A, Zhang H, Guyot R, et al. Evidence for hormonal control of heart regenerative capacity during endothermy acquisition. Science. 2019;364:184-8.

13. Patel V, Singh VP, Pinnamaneni JP, Sanagasetti D, Olive J, Mathison M, et al. p63 silencing induces reprogramming of cardiac fibroblasts into cardiomyocyte-like cells. J Thorac Cardiovasc Surg. 2018;156: 556-65.e1.

14. Pascual A, Aranda A. Thyroid hormone receptors, cell growth and differentiation. Biochim Biophys Acta. 2013;1830:3908-16.

15. Magovern CJ, Mack CA, Zhang J, Hahn RT, Ko W, Isom OW, et al. Direct in vivo gene transfer to canine myocardium using a replication-deficient adenovirus vector. Ann Thorac Surg. 1996;62:425-34. 